医機学 Vol.84, No.4 (2014) ( 95 )

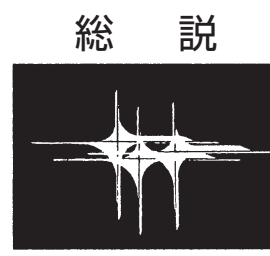

\title{
(一般財団法人 日本医科器械資料保存協会「医科器械史研究賞]受賞論文)
}

\section{鮒田式胃壁固定具の開発一胃瘻の歴史から見た鮒田式胃壁固定具の意義一 に関する研究報告}

\section{1.はじめに}

胃瘻は 1822 年にその安全性が確認されて以 降，さまざまな遍歴を経て，現在の低侵襲で簡 便な術式である経皮内視鏡的胃瘻造設術（Percutaneous endoscopic gastrostomy=PEG) へ と発展した。またこの発展の過程では併用さ れるさまざまな独自の医科器械が開発され，そ の普及の基盤となった.

本邦では, PEG は 2012 年 12 月現在，年間 約 10 万症例が実施されており ${ }^{1)}$ ，またその普 及過程に平行し, 術中及び術後瘦孔形成期間中 に，何らかの原因で胃壁と腹壁が離開した場合 の重篤な合併症を防止する有効な手段として, 胃瘦の本穿刺前に胃壁と腹壁を縫合固定する胃 壁固定法とそれに用いられる器具も同時に発展 を遂げた。特に本邦では, 鮒田式胃壁固定具 (Funada-style Loop Gastropexy Device) を用 いた経皮的胃壁固定法 (Percutaneous Gastropexy $=$ PG） が広く認知され PEG 全施行症 例の $41.1 \%$ にあたる年間約 41,000 症例に用い られるに至った2).

PGに用いられる鮒田式胃壁固定具は 1990 年に考案され，1991 年に第 41 回日本消化器内 視鏡学会総会 ${ }^{3)}$ と第 42 回日本消化器内視鏡学 会総会ビデオシンポジウム ${ }^{4)}$ にて発表をおこな い, 1993 年にクリエートメディック社から市 販化された。 また 2010 年にはワンハンドタイ プ鮒田式胃壁固定具 II の市販化も開始された.

鮒田昌貴 *

本研究報告では「胃瘦の歴史に関する年表」(表 1 ）のごとく開腹的胃瘻造設術の歴史, PEG の歴史，胃壁固定法と胃壁固定具の歴史などの 史実を通して, 本邦で誕生した鮒田式胃壁固定 具の開発の経緯やその意義をそうした医学史及 び医科器械史の観点から検証を試みる.

\section{2. 開腹的胃瘻造設術の歴史}

胃瘻の歴史は, アメリカの軍医 William Beaumont が 1822 年 6 月 6 日に銃外傷により 左胸部の皮膚と胃にトンネル (胃瘻) が出来た 28 歳患者の治療をおこなった 1825 年の報告 ${ }^{5}$ にはじまる（図 1)。当該症例に関しては，胃 瘦から直接食物を入れた観察もおこないその患 者 Alexis St. Martin はその後 58 年間生存した (図 2 ).

人工的な胃瘦造設といえば, かつては開腹的 外科手術を意味し, 経口摂取不能となった患者 に，腹壁より胃に穴をあけて直接胃内に食物を 送り込む考えが，1837年ノルウェーの軍医 Christian August Egebergによって発案された。

1849 年にはフランスの外科医 Charles Sedillotにより初めて人に施行され, fistulous gastrostomy（胃瘦孔形成術）と命名された. 9 年間で 3 人に施行したが, 結果は失敗に終わ り，全例腹膜炎で患者は死亡した。

その後, 何人かによって胃瘦孔形成術が試み られたが, 1875 年にイギリスの外科医 Jones Sydney が施行したのが最初の成功例とされて いる.

* ふなだ外科内科クリニック

1891 年にドイツの外科医 Oskar Friedrich 


\section{表 1 胃瘻の歴史に関する年表}

\section{開腹的胃瘻造設術の歴史}

\begin{tabular}{|c|c|}
\hline \multicolumn{2}{|r|}{ 開腹的胃瘻造設術の歴史 } \\
\hline $\begin{array}{l}1822 \text { 年 } \\
1825 \text { 年報告 }\end{array}$ & 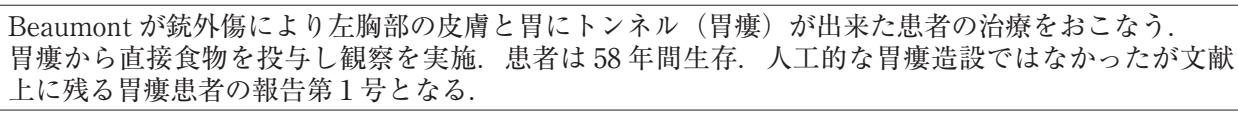 \\
\hline 1837 年 & $\begin{array}{l}\text { 経口㩒取不能となった患者に対し開腹的外科手術により腹壁より胃に穴をあけて直接胃内に食物を送 } \\
\text { り込む方法が Egebergによって発案. }\end{array}$ \\
\hline 1849 年 & $\begin{array}{l}\text { 開腹的外科手術による胃瘦造設を Sedillot が初めて人に施行. fistulous gastrostomy（胃㾇孔形成術） } \\
\text { と命名. } 9 \text { 年間で } 3 \text { 人に施行したが全例腹膜炎で患者は死亡. }\end{array}$ \\
\hline 1875 年 & 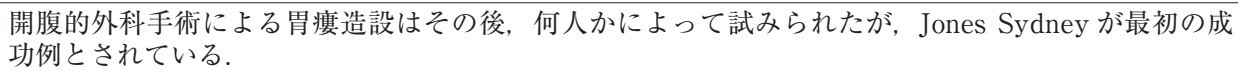 \\
\hline 1891 年 & Witzel が開腹手術による胃㾇造設の実施に関して報告. \\
\hline 1894 年 & 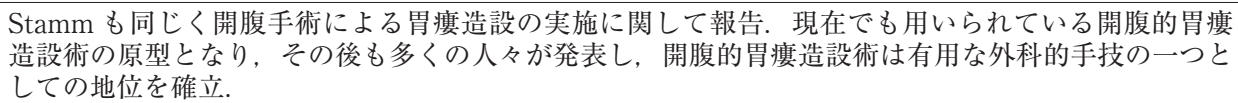 \\
\hline \multicolumn{2}{|r|}{ 経皮内視鏡的胃瘻造設術の歴史 } \\
\hline 1978 年 & $\begin{array}{l}\text { Hashiba が世界初の胃壁固定を実施した Introducer 法による経皮内視鏡的胃瘦造設術（PEG）を実施. } \\
\text { サンパウロ医学協会外科部にて登. }\end{array}$ \\
\hline 1979 年 & $\begin{array}{l}\text { Gauderer が Ponsky の協力を得て, 神経障害のために嚥下障害を有する } 6 \text { 歳児に経皮内視鏡的胃瘦造 } \\
\text { 訹 } \\
\end{array}$ \\
\hline 1980 年 & $\begin{array}{l}\text { Hashiba がサンパウロ医学誌 } 95 \text { にポルトガル語論文を掲載. Gauderer と Ponsky の英文による国際 } \\
\text { 的学会誌への報告に遅れをとる. }\end{array}$ \\
\hline 1981 年 & $\begin{array}{l}\text { Preshaw が, introducer 法のもとになる内視鏡を用いずにレントゲン透視下で胃内に挿入されたバ } \\
\text { ルーンに空気を注入して胃を膨らませ, 腹壁より直接穿刺して胃瘻を造設する方法を考案. }\end{array}$ \\
\hline 1983 年 & 上野，門田が内視鏡を用いた introducer 法の手技を発表. \\
\hline 1984 年 & Russell らも同様に introducer 法の手技を発表. \\
\hline \multicolumn{2}{|r|}{ 胃壁固定法（PG）と胃壁固定具の歴史 } \\
\hline 1986 年 & Cope がレントゲン透視下で胃壁と腹壁を固定する Gastrointestinal suture anchor という器具を発表. \\
\hline 1986 年 & Brown がレントゲン透視下で T-fastener という器具を用い胃壁と腹壁を 4 点固定する方法を発表. \\
\hline 1987 年 & Wu TK らが T-fastener を用いた PEG を報告. \\
\hline 1990 年 & $\begin{array}{l}\text { 魴田が第 } 40 \text { 回日本消化器内視鏡学会総会と同学会第 } 33 \text { 回東海地方会にて, Gastrointestinal suture } \\
\text { anchor の問題点を指摘し, 新しい胃壁固定器具の開発が望まれることを示す. }\end{array}$ \\
\hline 1990 年 & Cope が suture anchor の改良を発表. \\
\hline 1990 年 & 鮒田式胃壁固定具の開発が完了. \\
\hline 1991 年 & 鮒田が鮒田式胃壁固定具を第 41 回及び第 42 回日本消化器内視鏡学会総会にて発表. \\
\hline 1993 年 & 鮒田式胃壁固定具市販化. \\
\hline 1998 年 & $\begin{array}{l}\text { 上野・門田式の introducer 原法を実施するための PEG キットである経皮的瘦用カテーテルキット（ク } \\
\text { リエートメディック社）に鮒田式胃壁固定具が組み込まれる. }\end{array}$ \\
\hline 2010 年 & ワンハンドタイプ鮒田式胃壁固定具 II 市販化. \\
\hline
\end{tabular}

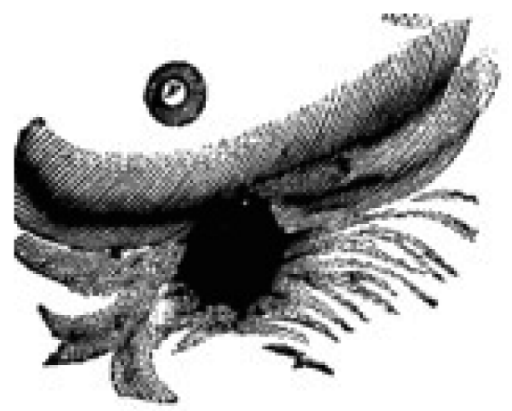

図 1 銃外傷により出来た左胸部の皮膚と胃のト ンネル（胃瘻）

出典：文献 5

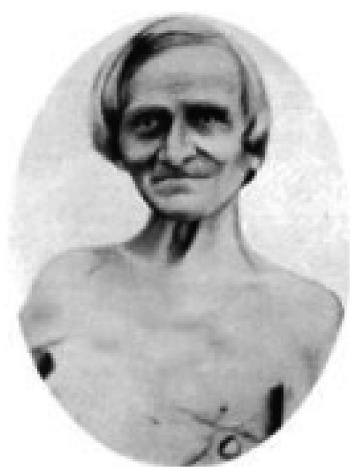

図2 81 歳の Alexis St. Martin

出典 : Myer,Jesse S. (1912). Life and Letters of Dr. William Beaumont. St.Louis : C.V.Mosby Company. 298. 
医機学 Vol.84, No. 4 (2014) ( 97 )
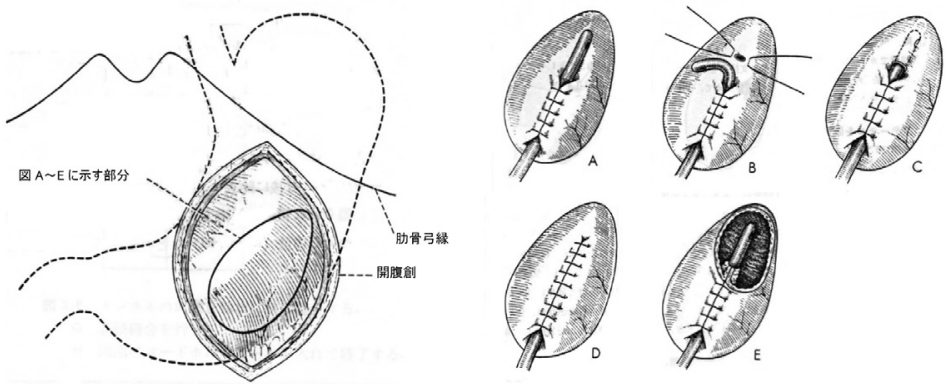

図3 Witzel 手術

出典 : 白鳥常男. 胃瘦造設術. 現代外科手術学大系 12 胃・十二指腸の手術 (木本誠二 監修)。東京；中山書店, $1981: 23$
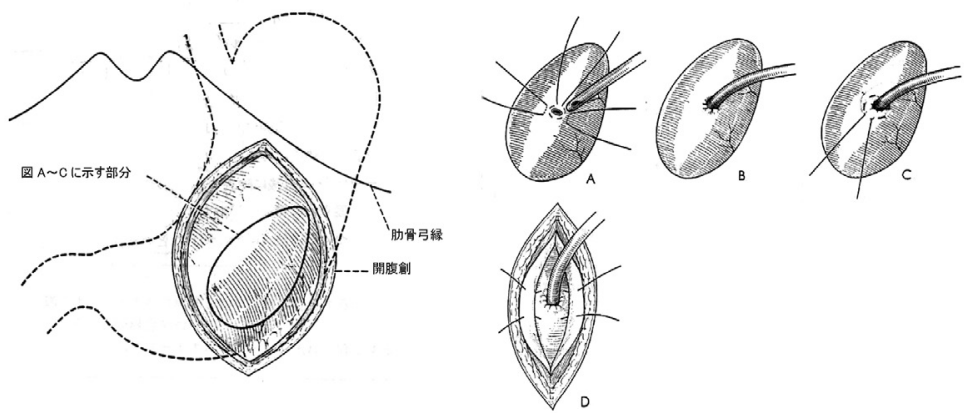

図4 Stamm 手術

出典：白鳥常男. 胃瘦造設術. 現代外科手術学大系 12 胃・十二指腸の手術 (木本誠二 監修)。東京 ; 中山書店, $1981: 25$

障害を有する 6 歳児に経皮内 視鏡的胃瘻造設術 (PEG) を おこない成功した。従来, 開 腹を要していた胃瘻造設を，局 所麻酔下で開腹をせず内視鏡 を用いておこなう新手技であ る.この画期的な手技が小児 外科と消化器内視鏡の両分野 で報告 ${ }^{6,7)}$ されて以来，たちま ち脚光を浴びた.PEGの考案 により，開腹的胃瘦造設術の 利点はそのままに，欠点の多 くが克服され，急速な普及を みることになる。すなわち，全 身麻酔が不要で短時間でおこ なえ，腹部に切開創を加えな いために回復も早いという低 侵襲性と簡便性に優れ，経済 的でもある。

これまで本邦で知られてき たPEGの歴史では, Gauderer と Ponsky らの報告が世界で最 初の PEG 成功例とされていた が, 本研究の過程でその約 1

Witzel が, 1894 年にはアメリカの外科医 Martin Stamm が，それぞれ開腹手術による胃瘦造設 の実施に関して報告（図 3, 図 4) し, 現在で も用いられている開腹的胃瘦造設術の原型とな り, その後も多くの人々が発表し, 開腹的胃瘦 造設術は有用な外科的手技の一つとしての地位 を確立してきた. しかし, 当時, 胃瘦造設を必要 とするのは末期の患者が多く, 栄養状態も極度 に悪くハイリスクであった。現在でも，開腹的 胃㾞造設術は, 手術室で多くの場合全身麻酔下 でおこなわれ，あくまでも開腹手術の一つであ り全身状態の悪い患者には施行できなかった.

\section{3. 経皮内視鏡的胃瘻造設術 (PEG) の歴史}

1979 年 6 月オハイオ州クリーブランドにあ る Case Western Reserve 大学付属病院で, 小 児外科医の Gauderer は内視鏡外科医である Ponsky の協力を得て, 神経障害のために嚥下
年前の 1978 年にブラジルの日系人医師 Kiyoshi Hashiba が世界初の胃壁固定をした Introducer 法をおこない, 同年 10 月 10 日にサンパウロ医 学協会外科部にて発表をおこなっていることが 明らかとなった。 また, 彼が 1980 年 1 月 23 日 付でサンパウロ医学誌 95 に承認された論文 ${ }^{81}$ はポルトガル語で書かれており, 同年内の Gauderer と Ponsky の英文による国際的学会 誌への報告に遅れをとったものと考えられる. 彼の報告は，内視鏡下で胃壁と腹壁を貫通した 1 本の針からリング状にした糸を出し別の 1 本 の針に施された小さな溝及びマンドレルで糸を 引っ掛けて 2 本とも引き抜くと腹壁外から胃壁 腹壁を貫通して糸が Uターンして腹壁外へも どってくるという発想である（図 5 )。しかし, 実際にはきわめて難しい方法で, 特に系をリン グ状に開くのは困難ではないかと推測する。そ の後, Hashiba の胃壁固定の発表はなく胃壁固 定具の実用化もされていない，史実としては 

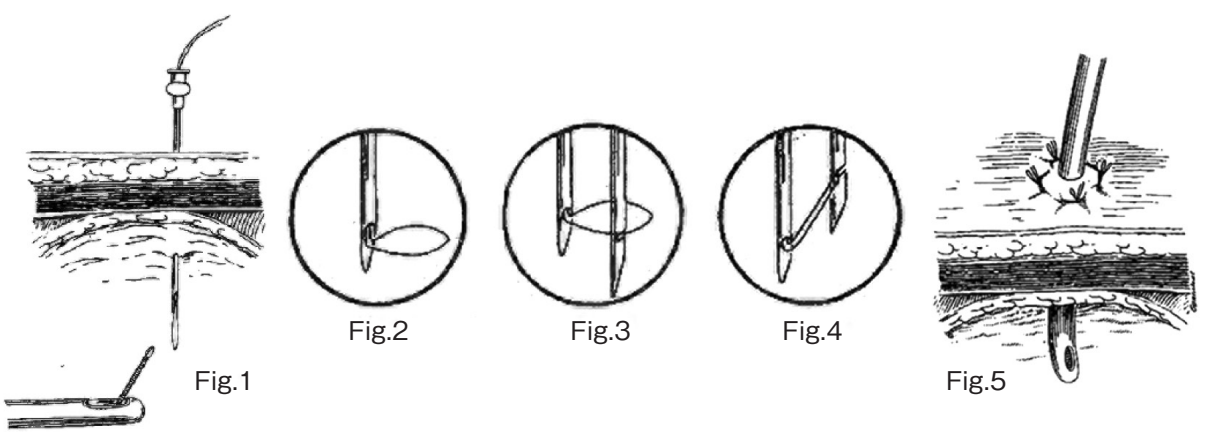

図5 Hashiba の胃壁固定法

出典：文献 8

Hashiba が実施したものが現時 点では最初の PEGの成功例であ り, 同時に最初に実施された $\mathrm{PG}$ であると考えられるが, 実用段階 には至っていないと考えられる。

現在, 本邦で主に実施されて いる PEGには, 大きく分けて 3 通 りの方法がある. 前述のGauderer とPonskyによりおこなわれた 方法は pull 法と呼ばれる。この 方法は, 腹壁から挿入したガイ ドワイヤーを一旦口から外に出

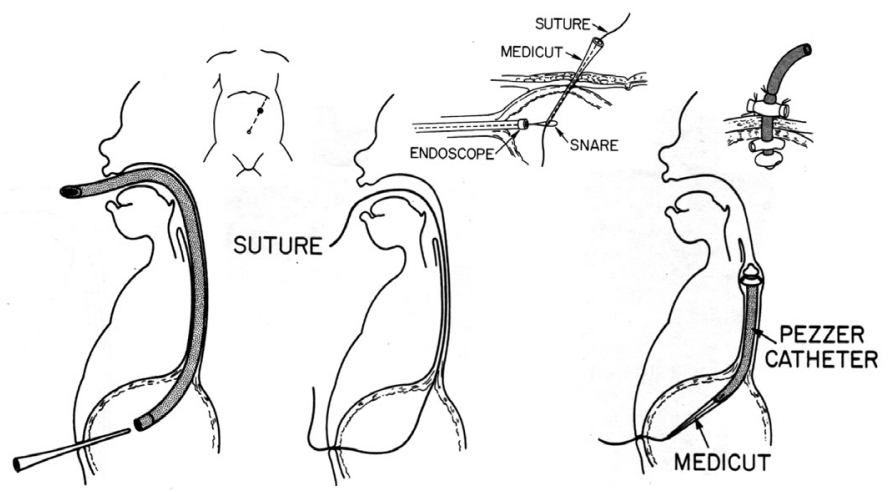

図6 Pull 法

出典: 文献 6

し, このガイドワイヤーに胃㾇 チューブを結んで口から胃の中 に引き入れ腹壁外に出す方法で ある（図 6)。1983 年には Sacks と Vine らにより push 法が発表 ${ }^{9)}$ された.この方法は, ガイドワ イヤーを腹壁から挿入して一旦 口から外に出した後に, ガイド ワイヤーに添って胃瘦チューブ を胃の中に押し込み腹壁外に出 す方法で, サックス・バイン法,
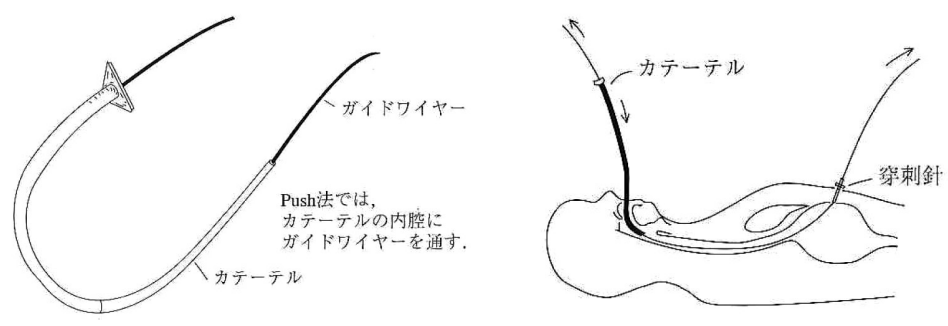

図7 Push 法

出典 : 上野文昭, 嶋尾仁, 門田俊夫ほか: 経皮内視鏡的胃瘦造設術と 在宅管理. 日本医学中央会 (メディカル・コア) : 11-20

プッシュワイヤー法とも呼ばれ

ている(図 7 ).

また, 1981 年に Preshaw は, introducer 法 のもとになる内視鏡を用いずにレントゲン透視 下で胃内に挿入されたバルーンに空気を注入し て胃を膨らませ，腹壁より直接穿刺して胃瘦を 造設する方法を考案 ${ }^{10)}$ した。

その後, 1983 年には上野, 門田 ${ }^{11)}$ が 1984 年 にはRussell ら ${ }^{12)}$ が，内視鏡を用いた intro- ducer 法の手技を発表した(図 8).この方法は, 腹壁からトロカールを介して直接胃瘻チューブ を挿入する方法で，内視鏡の挿入が一回ですむ こと, 感染の危険が少ないなどの利点がある. しかし，初期の introducer 法には，バルーン の破裂や脱気によるチューブ逸脱, 造設チュー ブ径が細いこと, 太い穿刺針による損傷の懸念 などが欠点として知られており, 数々の技術改 

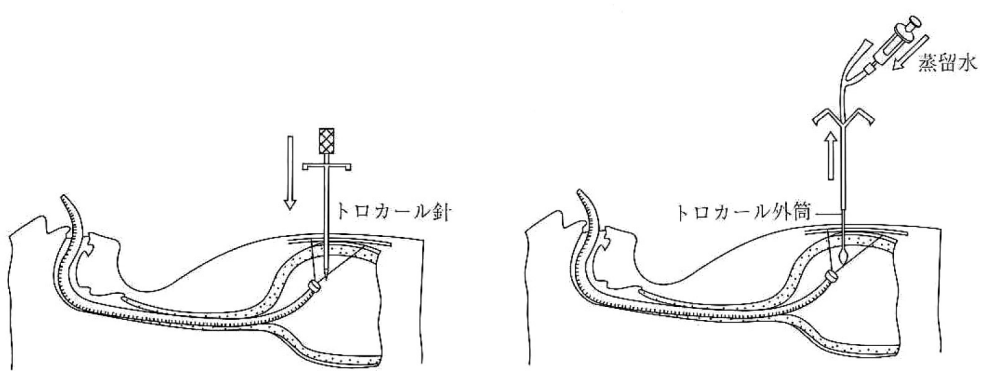

図8 Introducer 法

出典：上野文昭, 嶋尾仁, 門田俊夫ほか: 経皮内視鏡的胃瘦造設術と

在宅管理. 日本医学中央会（メディカル・コア）：21-33

良がなされた。

PEG は内視鏡だけでなく，その手法ごとに 上記のごとく穿刺針やトロカール，ダイレー ターやシース，ガイドワイヤーやチューブなど の器具が使用され，それらがキット化された $\mathrm{PEG}$ キットが用いられる。本邦でも，さまざ まな方式を基本に, 種々の工夫が加えられた PEG キットが $7 \sim 8$ 種類, 製造あるいは輸入 されて市場に出ている.

\section{4. 経皮的胃壁固定法（PG）亡胃壁固 定具の歴史}

1989 年, 鮒田は三重県四日市市にある小山 田記念温泉病院にて, 上野・門田式 introducer 法による PEGをおこなった際，術中患者が咳 をしてシースが胃から抜けてしまい, 開腹手術 への変更を余儀なくされた. 初心者でも安全に かつ確実におこなえる方法を考案する必要性を 強く感じた. 具体的には, 本穿刺を㧍こないカ テーテルを挿入する前に, 胃壁と腹壁を固定す る必要があると考えた。これが鮒田式胃壁固定 具の開発のきっかけである.

鮒田が器具の開発を進めていくうちに, Cope がレントゲン透視下で胃壁と腹壁を固定する Gastrointestinal suture anchor という器具が 1986 年に発表 ${ }^{13)}$ されていることを知り, 臨床 使用した。

Cope Gastrointestinal suture anchor (図 9) は中央に糸が付いたコイル状の 1 センチ前後の 金属製のアンカーが穿刺針内に仕込まれたもの で，経皮的に胃内に穿刺した後にガイドワイ ヤーを穿刺針内腔に抻入することでアンカーを
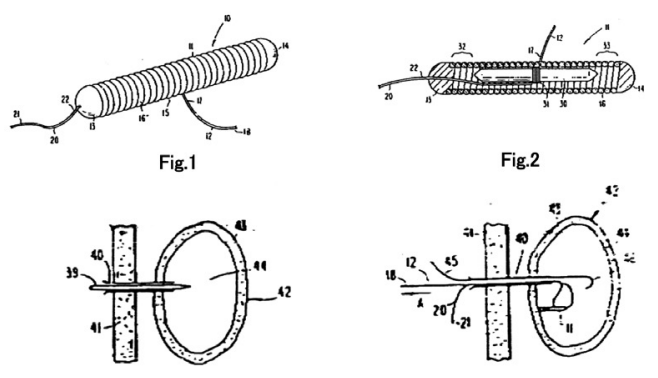

Fig.3
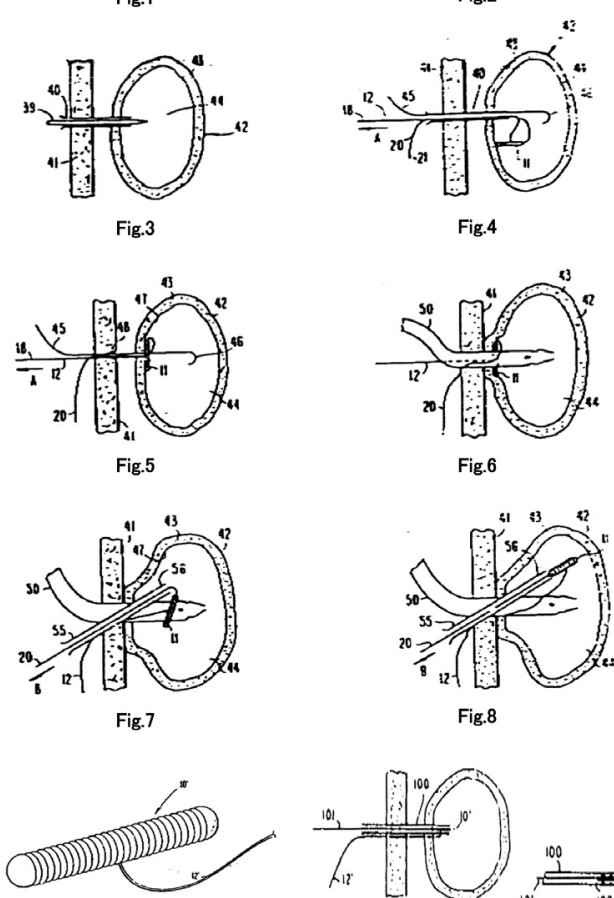

Fig.9
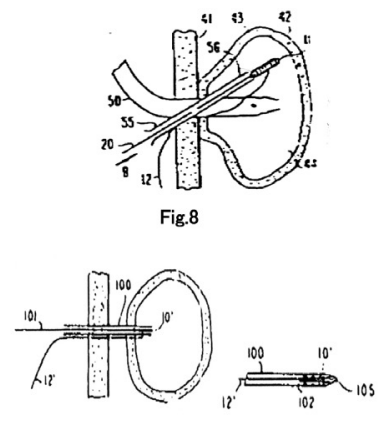

Fig.10

Fig.10A

図9 Cope Gastrointestinal Suture Anchor

日本国特許庁 公開特許公報 (A) 昭 63-23651 特許図面より 引用

胃内腔に押し出し胃壁を吊り上げる構造であっ た。臨床使用では胃内腔に押し出す直前に, 空 気で膨張させた胃がしぼんでしまい胃壁から穿 刺針が抜け，同時にアンカーが腹腔内に留置さ れてしまい開腹手術によりそのアンカーを摘出 しなくてはならない不具合を経験した。 また瘻 
(100) 医機学 Vol.84, No.4 (2014)

孔形成期間後に腹壁外の糸を切断することによ りアンカーを胃内に落とし，下剤により体外に 排出させるように当時の添付文書に記載があっ たが，異物であるアンカーが胃内腔に残留した り小腸や大腸に留まり腸管壁に刺さって出血や 穿破したり腸閉塞の原因となることも考えら れ，やむなく内視鏡を用いて回収をおこなう必 要があった。ささらに時間の経過と共にアンカー が胃粘膜に埋没し回収することができない症例 も経験した（図 10）。一方，腹壁外から縫合系 を用いて縫合固定を行う鮒田式胃壁固定具を使 用すれば，アンカーを胃粘膜に埋没させること なく，また，術後内視鏡を挿入してアンカーの 抜去をおこなうという久点をもたず，腹壁外か ら縫合糸を切断し抜去することで体内に異物を 残さない.

この使用経験に関して鮒田は, 1990 年, 第 40 回日本消化器内視鏡学会総会 ${ }^{14)}$ と同学会第 33 回東海地方会 ${ }^{15}$ ) で発表し, Gastrointestinal suture anchorの問題点を指摘し, 新しい胃壁 固定器具の開発が望まれることを示した。

また, 後日の文献検索では, 1986 年 Brown が レントゲン透視下で T-fastener という器具を 用い胃壁と腹壁を 4 点固定する発表 ${ }^{16)}$ が存在 していることを知った. 1987 年には Wu TK らが T-fastener を用いたPEGを報告 ${ }^{17)} し, 1990$ 年にはCope が suture anchor の改良発表 ${ }^{18)}$ おこなっていることも判明した。

考案，自作した鮒田式胃壁固定具は，糸把持 用ループを仕込んだ $17 \mathrm{G}$ 硬膜外針と糸挿入用 $17 \mathrm{G}$ 直針を同方向に並列一体化した胃壁固定用

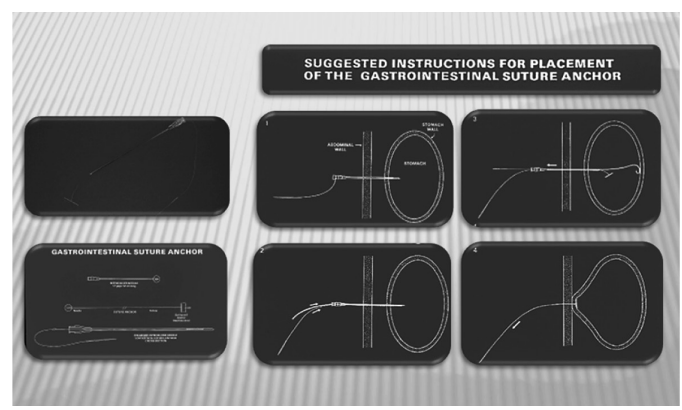

図10臨床使用した Gastrointestinal Suture Anchor

出典：文献 13
特殊針（以下特殊針）で, 特殊針一対の 2 本針 タイプ（図 11）は1990年 9 月 25 日に, 厚生 省（現厚生労働省）の確認及び小山田記念温泉 病院の倫理委員会での承認を経て 69 歳女性に 臨床使用された。特殊針二対の 4 本針夕イプ (図 12) は, 一回の 4 針同時穿刺で 2 ヶ所の胃 壁固定を同時におこなうことができ，1990 年 10 月 19 日 89 歳女性に臨床使用された。2 本 針タイプ，4本針タイプのいずれも手術は成功 した22.

自作胃壁固定具の 2 本針タイプは, $17 \mathrm{G}$ 硬膜 外針と $17 \mathrm{G}$ 直針及びポリペクトミー用スネア を用い, $10 \mathrm{ml}$ 用ディスポーザブル注射器内筒 の柄の部分を切り取り，2本針の固定とねじれ や広がり防止目的として二カ所に使用してい る. 4 本針タイプは， $60 \mathrm{ml}$ 用ディスポーザブ ル注射器外筒の点線枠部分を切り取り，4本針 の固定とねじれや広がり防止目的として二力所 に使用している。

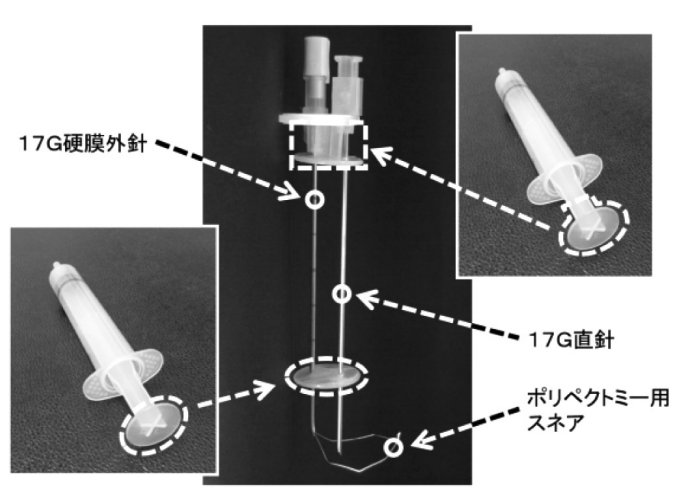

図 11 自作䱦田式胃壁固定具2本針タイプ

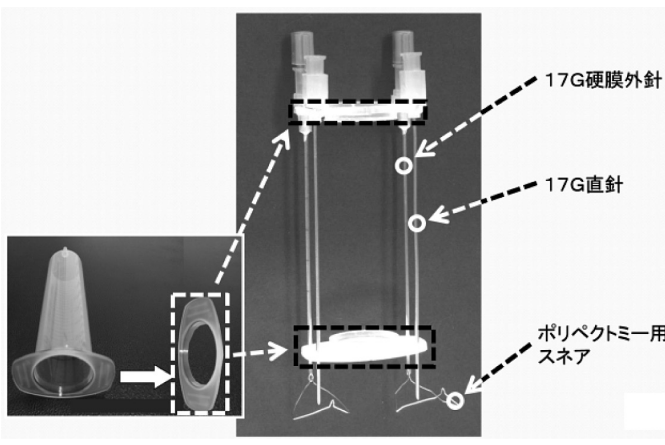

図12 自作鮒田式胃壁固定具4本針タイプ 
医機学 Vol. 84, No. 4 (2014) (101)

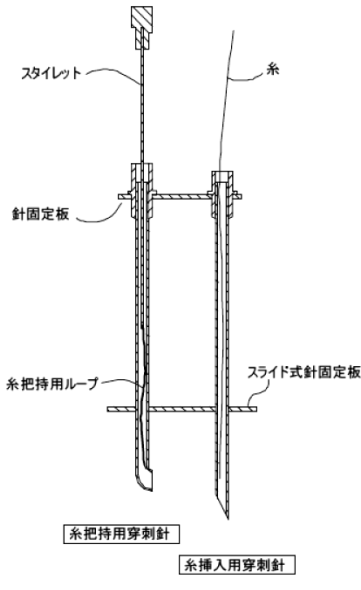

A

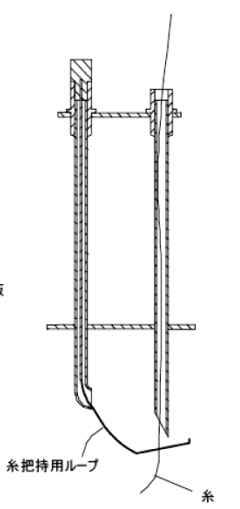

B

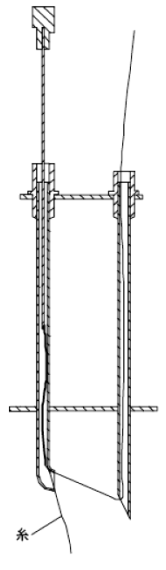

C
れる. 従来の方法は, 瘦孔完成まで の間は胃壁と腹壁との間の固着を胃 瘻チューブによる毫引にすべてを 頼っており, 術中のトラブルや術後 のチューブの損傷・患者自身の抜去 などにより胃壁と腹壁の離開が起こ りうる.」とその開発理由を記載し ている。すなわち, 自らの苦い経験 から同じ失敗を他の医師もすること のないよう，初心者でも PEGをよ り安全により確実に出来るようにす るかが開発の動機であった。

その後の臨床使用及び研究開発に より，特殊針は $20 \mathrm{G}$ 直針となり 2 本 針タイプが 1993 年 5 月 23 日, クリ エートメディック社にて製品化された。（図 14）

\section{PG の普及における鮒田式胃壁固 定具の意義}

1993 年 5 月 23 日に鮒田式胃壁固定具が市販 化されて以降, この器具は, 本邦において $\mathrm{PG}$ の普及に貢献した。本邦で考案され普及した Introducer 法には PG が必要不可欠であった 事，意識障害のある高齢者等にも PEG が施行 されており，自己抜去などを原因とした胃壁と 腹壁の離開の発生が散見されたことなどが普及 の要因としてあげられる.

また，術前に PGを実施することにより， PEG 施行時や瘦孔形成期間中に発生するトラ ブルに起因した胃壁と腹壁の離開の防止が可能 となり，自己抜去や事故抜去において胃瘦力 テーテルが逸脱した場合であってもすぐに再挿 入が可能となった。 また, 瘦孔形成期間中に発 生する目詰まりなどのカテーテルトラブルに対 してもカテーテルを安全に交換することが可能 となった。この他にも $\mathrm{PG}$ を実施することによ り癌患者等で腹水のある症例への PEG の適応 を可能としたＰG を実施した上で実施された PEG では瘦孔周囲の胃壁と腹壁の癒着が強固 となり, 瘦孔形成後のカテーテル交換もより安 全におこなえる。このようにPG は PEGの安 全性向上に大きく寄与することが広く認識され たことが本邦での普及の一因と言える.

図 14 鮒田式胃壁固定具（クリエートメディック社） 


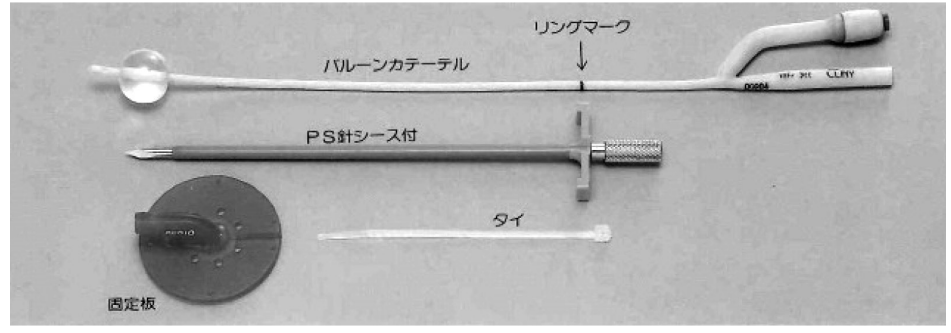

図 15 門田・上野式経皮内視鏡的胃瘦造設術キット 初期の経皮的瘻用カテーテルキット (クリエートメディック社)
り,これらの縫合糸はきわめて コシがあり, 現在, 主に使用さ れているナイロン糸などと比較 して, 挿入性はきわめて良好で あった，その後, 生物由来材料 の医療での使用に規制があり， クロミックカットグート等の吸収 性縫合糸が販売中止されたこと から,こうした要望が顕在化し たものと思われた。

鮒田式胃壁固定具を用いた PG は，上野・門 田式の introducer 原法の最大の欠点である胃 壁と腹壁の離開による腹膜炎併発の防止に大き く寄与し, 1998 年 5 月 31 日には上野・門田式 の introducer 原法を実施するための PEG キッ トである経皮的瘻用カテーテルキット（クリ エートメディック社）（図 15）に鮒田式胃壁固 定具が組み込まれる形で市販化されている.ま た, 1991 年の学会発表後, 多くの臨床医により 鮒田式胃壁固定具の有用性が数多く報告され, 新たな術式である Direct 法(現在の introducer 変法)も鮒田式胃壁固定具を使用して開発され

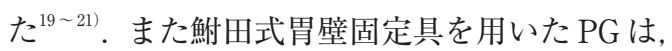
胃壁と腹壁の癒着強度を強化することがで き ${ }^{22 .}{ }^{23)}$, 胃瘦用カテーテルの交換時の安全性の 向上に貢献し，1993 年 5 月に市販化されてか ら 2014 年 5 月末の約 22 年間で国内では約 52 万症例以上, 2002 年以降に発売された国外で は約 5 万症例以上（クリエートメディック社調 べにに使用されている.

なお，鮒田式胃壁固定具が開発された 1990 年から 2014 年 5 月末現在までに使用された延 ベ約 57 万本 (クリエートメディック社調べ) に関して，重篤な合併症は現在まで 1 例も報告 されていない. 但し, 縫合糸の 挿入性の向上及び糸把持用ルー プの操作のワンタッチ化を望む 声が散見されるようになった。 縫合糸の挿入性に関しては鮒田 式胃壁固定具の開発当初は使用 する縫合糸として，クロミック カットグート等に代表される吸 収性縫合糸の使用を推奨してお

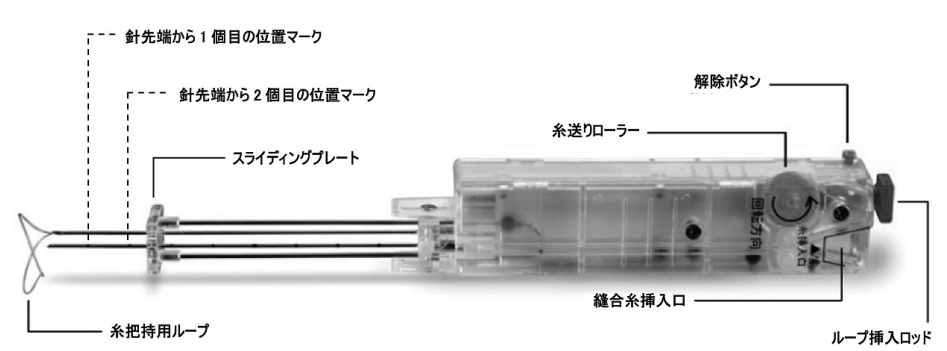

図 16 鮒田式胃壁固定具 II (クリエートメディック社) 
医機学 Vol.84, No. 4 (2014) (103)

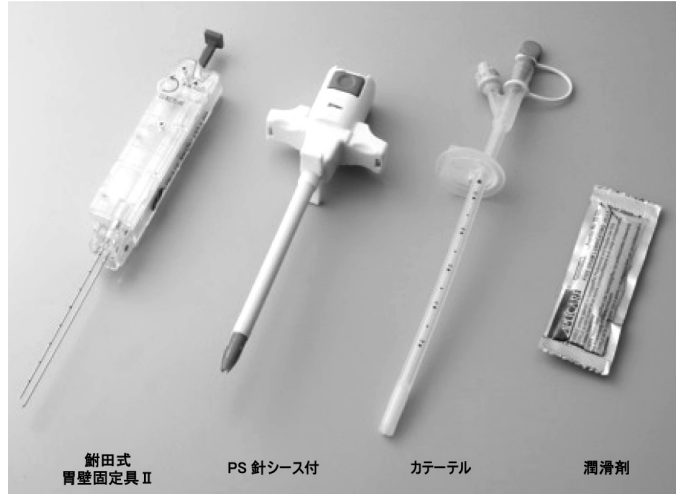

図 17 イントリーフPEGキット(クリエートメディック社)

鮒田式胃壁固定具 II を用いた PG は下記の方 法により八つのステップでおこなわれる2)(図 18). (1) PGの施行前に縫合糸捙入口より縫合糸を 挿入し，ローラー部を回転させて縫合糸を糸 挿入用穿刺針の先端近傍まで挿入しておき, スライディングプレートを穿刺針の先端か ら 1 個目と 2 個目の位置マークの間（針先端 から $1 \sim 2 \mathrm{~cm}$ の間) にセットしておく.

(2) 左側臥位にした患者の胃内に内視鏡を挿入 後, 十分に送気して胃前壁を腹壁に密着さ せ，その後患者を仰臥位にする。内視鏡から の透過光や腹壁を指先で圧迫して胃前壁の

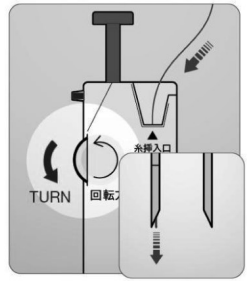

1

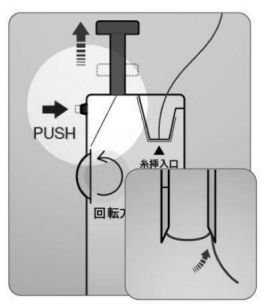

5

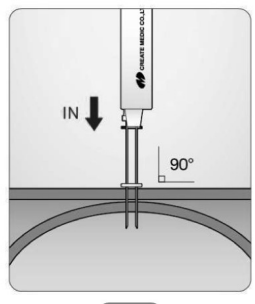

2

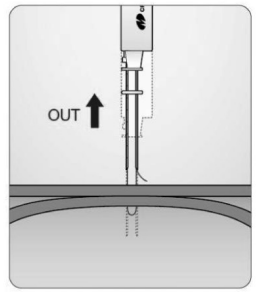

6

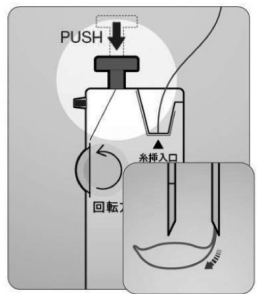

3

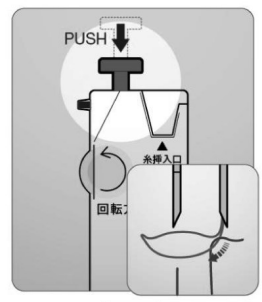

7

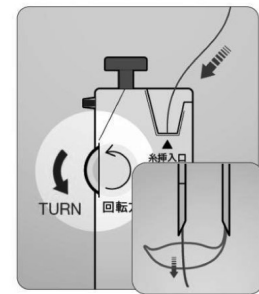

4

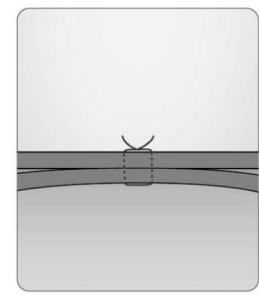

8

図 18 鮒田式胃壁固定具 I の経皮的胃壁固定法手技手順 
し，胃前壁と腹壁が固定される.さらに, この 結紮部分より $2 \sim 3 \mathrm{~cm}$ 離れて平行に同様の 処置をおこない, 胃壁固定が完了する.

ワンハンドタイプ鮒田式胃壁固定具 II は, 上 記のごとく腹壁への穿刺, 糸把持用ループの突 出, 縫合糸の挿入, 縫合糸の把持までのこれら 一連の操作を片手でおこなえるような機構を持 つ.これにより術者は手元を見ることなく内視 鏡の画面を注視することができ，PG を更によ り安全に，また簡便におこなえることができる ようになった。 また，片手で操作可能となった ことから PEG One Man Methodを可能とし, PEG に新たな可能性を提供した.

なお, 鮒田式胃壁固定具は, 2002 年よりド イッ・イタリア・オーストリア・韓国・シリアに, 2006 年より中国に, 2010 年よりイランに, 2011 年よりペルー・香港に輸出されており, 近年, ヨーロッパを中心に，日本国外でも鮒田式胃壁 固定具を用いた胃壁固定の論文報告 ${ }^{25 \sim 28)}$ がな され世界的評価を受けている。

\section{7. 結語}

本研究を通して，世界中の医師が同時期に同 じような課題を抱え, より良い術式や器具を志 向し, 常に最善の選択がおこなわれたことによ り現在のより低侵襲性と簡便性に優れた術式や 器具が普及したことが証明された。 鮒田式胃壁 固定具は, 190 年を超える胃瘻の歴史とその発 展の過程で誕生した医科器械史的にも意義のあ る器具であると言える。 また, PEGの発展と安 全性の向上に大きく寄与したことが認められる。

\section{文献}

1)「第25版医療用ディスポーザブル製品2013 年 版カテーテル＆チューブ, IVR製品市場の中 期予測と関連製品の徹底分析」大阪; 株式会 社 矢野経済研究所 ライフサイエンス事業部 医療機器部 発行, 2013 :488-499.

2 ) 鮒田昌貴: 鮒田式胃壁固定具 (Funada-style Loop Gastropexy Device)の誕生から改良型ワンハン ドタイプ鮒田式胃壁固定具 II の開発まで. 在宅 医療と内視鏡治療 $2013 ; 17$ （1）: 87-98.

3 ) 鮒田昌貴, 中川浩, 川村耕造ほか: 経皮内視
鏡的胃瘦造設術一胃壁固定法の新手技に関す る報告一. 第41回日本消化器内視鏡学会総会 抄 録. Gastroenterological Endoscopy 1991 ; 33 (12) : 2681.

4) 鮒田昌貴, 中川浩 : 経皮内視鏡的胃瘦造設術 一新手技「経皮的胃壁固定法」の実際一. 第 42回日本消化器内視鏡学会総会講演予報集抄 録.1991 : 233.

5 ) W. Beaumont: Beaumont's Experiments and Observations on the Gastric Juice and the Physiology of Digestion. $1833: 27$.

6 ) Gauderer MWL, Ponsky JL, Izant RJ : Gastrostomy without laparotomy : A percutaneous endoscopic technique. J Pediatr Surg 1980 ; $15: 872-875$.

7 ) Ponsky JL, Gauderer MWL : Percutaneous endoscopic gastrostomy : A nonoperative technique for feeding gastrostomy. Gastrointest Endosc $1981 ; 27: 9-11$.

8) Kiyoshi Hashiba : Técnica de abertura de gastrostomia sob controle e manipulação endoscópica. Revta Paul Med 1980 ; 95 : 37-38.

9) Sacks BA, Vine $\mathrm{H}$ et al: A Nonoperative Technique for Establishment of Gastrostomy in the Dog. Investigative Radiology $1983 ; 18$ : 485-487.

10) Preshaw RM : A Percutaneous Method For Inserting A Feeding Gastrostomy Tube. SGO $1981 ; 152$ : 659-660.

11）上野文昭, 門田俊夫 : 経皮内視鏡的胃瘦造設術 一簡易化された新手技に関する報告. Progress of Digestive Endoscopy $1983 ; 23: 60-62$.

12) Russell TR, Brotman $M$ et al : Percutaneous Gastrostomy ? A New Simplified and CostEffective Technique. Am J Surgery 1984 ; $148: 132-137$.

13) Constantin Cope : Suture Anchor for Visceral Drainage. American Journal of Roentgenology $1986 ; 146: 160-161$.

14）鮒田昌貴, 中川浩ほか: 経皮内視鏡的胃瘦造 設術一臨床的有用性の検討と胃壁吊り上げ具 の使用に関する報告一. 第40回日本消化器内 視鏡学会総会抄録. Gastroenterological En- 
doscopy $1991 ; 33$ ( 7 ) : 1500-1501.

15）鮒田昌貴, 中川浩ほか: 経皮内視鏡的胃瘦造設 術一胃壁吊り上げ具の臨床的有用性の検討一. 第33回日本消化器内視鏡学会東会地方会抄録.

Gastroenterological Endoscopy 1991 ; 33(4) : 868-869.

16) Brown AS, Mueller PR, Ferrucci JT : Controlled percutaneous gastrostomy : nylon Tfastener for fixation of the anterior gastric wall. Radiology 1986 ; 158 543-545.

17) Wu TK, Pietrocola D, Welch HF : New method of percutaneous gastrostomy using anchoring devices. Am J Surgery 1987 ; 153 : 230-232.

18) Coleman CC, Coons HG, Cope C : Percutaneous enterostomy with the Cope suture anchor. Radiology 1990 ; 174 : 889-891.

19）井上信行, 村上大介, 辻野晶子ほか: 新しい胃瘦 造設術Direct法の開発. Gastroenterol Endosc 44 (Suppl 1) : $2002 ; 564$.

20）井上信行, 長尾幸司, 中島佐知子ほか: 安全な 胃瘻造設法 “Direct法”. Gastroenterol Endosc 46 (Suppl 2) : $2004 ; 1892$.

21）中堀昌人, 長南明道, 板東ゆかりほか: Direct 法による経皮内視鏡的胃瘦造設術の経験. 在 宅医療と内視鏡治療 $2005 ; 9$ （1）: 51-55.

22）根本祐太, 嶋尾仁, 森瀬昌樹ほか: PEGカテー テル交換時のトラブルを起こしたが重大な合 併症を防止できた 2 症例. 在宅医療と内視鏡 治療 2002；6（1）: 43-45.
23）根本祐太, 森瀬昌樹, 嶋尾仁 : 内視鏡的胃瘦 造設（PEG）の腹壁固定の癒着の程度を観察 し得た 3 症例. 在宅医療と内視鏡治療 2003 ; 7 ( 1 ) : 43-45.

24）伊藤 徹, 稲木英治, 駒込早苗, 神 貴博, 鈴木芳敬 : 中村記念病院での一人法PEGの報 告. 静脈経腸栄養2008；23（2）: 299-300.

25) Wejda BUJ, Deppe H, Huchzermeyer H, Dormann AJ : PEG placement in patients with ascites : a new Approach. Gastrointest Endosc $2005 ; 61: 178-180$.

26) Giordano-Nappl JH, Maluf-Filho F, Ishioka S, et al : A new large-caliber trocar for percutaneous endoscopic gastrostomy by the introducer technique in head and neck cancer patients. Endoscopy $2011 ; 43$ : 752-758.

27) Teichgräber UK, Streitparth $\mathrm{F}$, Cho $\mathrm{CH}$, Gebauer B, Ricke J, Benter T : Percutaneous push-through gastrostomy by applying a CT-guided gastropexy. J Vasc Interv Radiol. $2011 ; 22$ : 1149-1152.

28) Bucourt M, Collettini F, Althoff C, Streitparth F, Greupner J, Hamm B, Teichgräber UK : CT fluoroscopy-guided percutaneous gastrostomy with loop gastropexy and peel-away sheath trocar technique in 31 amyotrophic lateral sclerosis patients. Acta Radiology $2012 ; 53: 285-291$. 